\title{
ARCHIVING OPTIMIZATION IN SAMSAT BOGOR CITY LINKED WITH POLICE REGULATION NOMOR 5 OF 2012 ON MOTOR VEHICLE REGISTRATION AND IDENTIFICATION
}

\section{OPTIMALISASI PENGARSIPAN DI SAMSAT KOTA BOGOR DIHUBUNGKAN DENGAN PERATURAN KAPOLRI NOMOR 5 TAHUN 2012 TENTANG REGISTRASI DAN IDENTIFIKASI KENDARAAN BERMOTOR}

\author{
Eka Sapari*, Dadang Suprijatna**, Mulyadi*** \\ Eka.sapari@unida.ac.id
}

(Diterima pada: 05-06-2017 dan dipublikasikan pada: 01-12-2017)

\begin{abstract}
Regident Ranmor aiming for orderly administration, control and supervision of motor vehicles in Indonesia, facilitate investigations offense or crime, planning, operational management and traffic engineering and transport road and national development planning. Regident Ranmor include new Ranmor registration, registration of identity change Ranmor and owners, registration or registration renewal and endorsement Ranmor. In addition to these activities regident Ranmor also includes blocking Ranmor regident documents related crime, replacement and deletion of documents regident Ranmor Ranmor registration number. The research method is needed to collect the amount of material used to answer the juridical analysis. Based on the problem, the research method used in normative juridical reseacrh method that is legal conceived as norms, rules, principles or dogmas. Mechanism archiving in Samsat Bogor City related to the Police Regulatins No. 5 of 2012 on Registration and Identifications of Motor Vehicles include: (1) Acceptance of the archive, (2) Labelling aechives, (3) the Sustainer archives made by some archivist assigned to maintain and secure confidentiality archives, and (4) Depreciation archives, Obstacles in the archiving on SAMSAT Bogor city linked with police Regulation No. 5 of 2012 on Registration and Identification of Motor Vehicles include: (1) lack of understanding of the importance of archives, (2) Increase in volume archives continuous basis, (3) There has guidelines working procedures archival, (4) the use of archives by the manager or by other parties that require long periods of time, and (5) can not or difficult rediscovery archives quickly and precisely. To overcome the problems that exist in archiving in order not to harm the institution, while the steps that can be taken include: (1) Must use storage system, (2) Need for regulating lending procedures in addition to supervision / control and control right, (3) Expanding the storage space and streamline the room as well as the existing equipment, (4) facilities archives should be qualified and with the times, (5) regularly held the treatment and prevention of damage, (6) the clerk records should be eligible, (7) Including the archives in courses or educational and training of archival and use of sophisticated technology, and (8) Conducting regular depreciation and destruction of the archives has been unused.
\end{abstract}

Keywords: Optimization, Archiving, Samsat

\begin{abstract}
ABSTRAK
Registrasi dan Identifikasi Kendaraan Bermotor (Regident Ranmor) bertujuan untuk tertib administrasi, pengendalian dan pengawasan kendaraan bermotor yang dioperasikan di Indonesia, mempermudah penyidikan pelanggaran dan atau kejahatan, perencanaan,
\end{abstract}

\footnotetext{
${ }^{*}$ Fakultas Hukum Universitas Djuanda Bogor, Jl. Tol Ciawi No 1, Kotak Pos 35 Bogor 16770

** Fakultas Hukum Universitas Djuanda Bogor, Jl.Tol Ciawi No I, Kotak Pos 35 Bogor 16770

****Fakultas Hukum Universitas Djuanda Bogor, Jl.Tol Ciawi No I, Kotak Pos 35 Bogor 16770
} 
operasional manajemen dan rekayasa lalu lintas dan angkutan Jalan dan perencanaan pembangunan nasional. Regident ranmor meliputi registrasi ranmor baru, registrasi perubahan identitas ranmor dan pemilik, registrasi perpanjangan ranmor dan atau registrasi pengesahan ranmor. Selain kegiatan tersebut regident ranmor juga meliputi pemblokiran dokumen regident ranmor yang terkait tindak pidana, penggantian dokumen regident ranmor dan penghapusan nomor registrasi ranmor. Metode penelitian diperlukan guna mengumpulkan sejumlah bahan yang digunakan untuk menjawab analisis yuridis. Bertitik tolak dari permasalahan, maka metode penelitian yang digunakan adalah metode penelitian yuridis normatif yaitu hukum dikonsepsikan sebagai norma, kaidah, asas atau dogma-dogma. Mekanisme pengarsipan di Samsat Kota Bogor berkaitan dengan Peraturan Kapolri Nomor 5 Tahun 2012 tentang Registrasi dan Identifikasi Kendaraan Bermotor meliputi: (1) Penerimaan arsip, (2) Pelabelan arsip, (3) Pemelihara arsip dilakukan oleh beberapa petugas arsip yang ditugaskan untuk memelihara dan mengamankan kerahasiaan arsip, dan (4) Penyusutan arsip. Kendala dalam pengarsipan pada Samsat Kota Bogor dihubungkan dengan Peraturan Kapolri Nomor 5 Tahun 2012 tentang Registrasi dan Identifikasi Kendaraan Bermotor diantaranya: (1) Kurangnya pengertian terhadap pentingnya arsip, (2) Bertambahnya volume arsip secara terus menerus, (3) Belum dimilikinya pedoman tata kerja kearsipan, (4) Penggunaan arsip oleh pengelola atau oleh pihak lainnya yang membutuhkan jangka waktu yang lama, dan (5) Tidak dapat atau sulit ditemukannya kembali arsip dengan cepat dan tepat. Untuk mengatasi masalah-masalah yang ada dalam pengarsipan di agar tidak merugikan lembaga, adapun langkah-langkah yang bisa ditempuh antara lain: (1) Harus menggunakan sistem penyimpanan yang tepat, (2) Perlu adanya pengaturan prosedur peminjaman di samping pengawasan/kontrol dan pengendalian yang tepat, (3) Memperluas tempat penyimpanan dan mengefektifkan ruangan serta peralatan yang ada, (4) Fasilitas kearsipan harus memenuhi syarat dan mengikuti perkembangan zaman, (5) Secara rutin diadakan perawatan dan pencegahan kerusakan, (6) Petugas arsip harus memenuhi syarat, (7) Mengikutsertakan para pengelola arsip dalam kursus-kursus atau diklat-diklat kearsipan dan penggunaan teknologi yang canggih, dan (8) Melakukan penyusutan dan pemusnahan secara rutin terhadap arsiparsip yang sudah tidak terpakai.

Kata Kunci : Optimalisasi, Pengarsipan, Samsat

\section{A. PENDAHULUAN}

Masyarakat merupakan suatu komponen penting dalam suatu negara, karena salah satu syarat agar suatu negara dapat dibilang negara adalah dengan terdapatnya masyarakat di dalamnya. Suatu negara dapat dibilang maju apabila masyarakat di dalamnya hidup dengan tenteram dan sejahtera. Oleh karena itu, untuk mewujudkan masyarakat yang demikian diperlukan sistem pemerintahan yang dapat memberikan pelayanan publik yang baik kepada masyarakatnya. Pelayanan publik kepada masyarakat merupakan salah satu tugas dan fungsi penting pemerintah dalam menyelenggarakan tugas-tugas pemerintahannya untuk menuju pemerintahan yang baik (good governance). ${ }^{1}$ Pelayanan publik merupakan unsur yang penting dalam penyelenggaraan pemerintahan karena menyangkut aspek kehidupan yang sangat luas.

1 Mochtar Kusumaatmaja, Konsep-konsep Hukum dalam Pembangunan, Bandung, Alumni, 2006, Hlm. 112 
Pelayanan publik atau pelayanan umum dapat didefinisikan sebagai segala bentuk jasa pelayanan, baik dalam bentuk barang publik maupun jasa publik yang pada prinsipnya menjadi tanggung jawab dan dilaksanakan oleh Instansi Pemerintah di Pusat, di Daerah, dan di lingkungan Badan Usaha Milik Negara atau Badan Usaha Milik Daerah, dalam rangka upaya pemenuhan kebutuhan masyarakat maupun dalam rangka pelaksanaan ketentuan peraturan perundangundangan. Pemerintah pada hakekatnya adalah pelayan masyarakat. Dalam kehidupan bernegara, pemerintah mempunyai fungsi memberikan pelayanan publik yang diperlukan oleh masyarakat terutama untuk memenuhi kebutuhan masyarakat dalam berbagai aspek kehidupan. $^{2}$

Kendaraan bermotor merupakan kebutuhan yang mungkin harus dipenuhi bagi masyarakat dalam melakukan aktivitas kehidupan sehari-hari. Menurut data Korps Lalu Lintas Kepolisian kendaraan bermotor yang masuk ke Indonesia mencapai 104.211 juta unit. Dengan banyaknya populasi unit kendaraan bermotor yang masuk ke Indonesia, registrasi dan identifikasi kendaraan bermotor sangat perlu dilakukan untuk memberi asal usul kendaraan bermotor. Berkaitan hal ini Tips Hukum akan menjelaskan apa tentang registrasi dan identifikasi kendaraan bermotor.

Berdasarkan Peraturan Presiden Republik Indonesia Nomor 5 Tahun 2015 tentang Penyelenggaraan Sistem Administrasi Manunggal Satu Atap Kendaraan Bermotor, bahwa Registrasi dan Identifikasi Kendaraan Bermotor yang selanjutnya disebut regident ranmor adalah fungsi Kepolisian untuk memberikan legitimasi asal usul dan kelaikan, kepemilikan serta pengoperasian ranmor, fungsi kontrol, forensik kepolisian dan pelayanan kepada masyarakat melalui verifikasi, pencatatan dan pendataan, penomoran, penerbitan dan pemberian

2 Rangkuti, Jasa Pelayanan. Bandung: Remaja Rosdakarya., 2008, Hlm.72 bukti registrasi dan identifikasi Ranmor, pengarsipan serta pemberian informasi.

Regident ranmor bertujuan untuk tertib administrasi, pengendalian dan pengawasan kendaraan bermotor yang dioperasikan di Indonesia, mempermudah penyidikan pelanggaran dan atau kejahatan, perencanaan, operasional manajemen dan rekayasa lalu lintas dan angkutan Jala dan perencanaan pembangunan nasional.

Regident ranmor meliputi registrasi ranmor baru, registrasi perubahan identitas ranmor dan pemilik, registrasi perpanjangan ranmor dan atau registrasi pengesahan ranmor. Selain kegiatan tersebut regident ranmor juga meliputi pemblokiran dokumen regident ranmor yang terkait tindak pidana, penggantian dokumen regident ranmor dan penghapusan nomor registrasi ranmor.

Samsat merupakan suatu sistem administrasi yang dibentuk untuk memperlancar dan mempercepat pelayanan kepentingan masyarakat yang kegiatannya diselenggarakan dalam satu gedung. Kantor bersama SAMSAT (Sistem Administrasi Manunggal Satu Atap) merupakan salah satu tempat pelayanan publik yang menangani pembayaran Pajak Kendaraan Bermotor (PKB), Bea Balik Nama Kendaraan Bermotor (BBNKB), pengesahan Surat Tanda Nomor Kendaraan Bermotor (STNK) dan Sumbangan Wajib Dana Kecelakaan Lalu Lintas Jalan (SWDKLLJ) yang akan selalu berubah menyesuaikan dengan kondisi perkembangan masyarakat yang selalu menuntut adanya peningkatan pelayanan publik.

Samsat merupakan suatu sistem kerjasama terpadu antara Polri, Dinas Pendapatan Provinsi, dan PT Jasa Raharja (Persero). Dalam hal ini, Polri memiliki fungsi penerbitan STNK, Dinas Pendapatan Provinsi menetapkan besarnya Pajak Kendaraan Bermotor (PKB) dan Bea Balik Nama Kendaraan Bermotor (BBNKB), sedangkan PT Jasa Raharja mengelola Sumbangan Wajib Dana Kecelakaan Lalu Lintas Jalan 
(SWDKLLJ). Lokasi Kantor Bersama Samsat umumnya berada di lingkungan Kantor Polri setempat, atau di lingkungan Satlantas/Ditlantas Polda setempat. Samsat ada di masing-masing provinsi, serta memiliki unit pelayanan di setiap kabupaten/kota. ${ }^{3}$

Arsip adalah rekaman kegiatan atau peristiwa dalam berbagai bentuk dan media sesuai dengan perkembangan teknologi informasi dan komunikasi yang dibuat dan diterima oleh lembaga negara, pemerintahan daerah, lembaga pendidikan, perusahaan, organisasi politik, organisasi kemasyarakatan, dan perseorangan dalam pelaksanaan kehidupan bermasyarakat, berbangsa, dan bernegara.(UU No. 43 Tahun 2009 tentang Kearsipan). ${ }^{4}$

Arsip yang dibuat dan diterima oleh institusi, badan atau lembaga perlu dikelola di dalam suatu sistem kearsipan yang baik dan benar. Mengingat bahwa kegiatan dan tujuan organisasi selalu berkembang selaras dengan tuntuan jaman dan keadaan, maka demikian juga dengan jumlah arsip/volume arsip yang dihasilkan dan diterima oleh organisasi ini. Kondisi demikian meniscayakan adanya sistem kearsipan di dalam organisasi. Dengan sistem kearsipan yang sesuai kebutuhan, sederhana dalam penerapan, dan mudah dilaksanakan diharapkan arsip yang masih memiliki nilai guna arsip bagi organisasi dapat digunakan secara optimal, ditemukan dengan cepat dan tepat jika dibutuhkan.

Dalam pengelolaan arsip, terdapat beberapa pekerjaan atau kegiatan kearsipan.

Pekerjaan atau kegiatan yang berkaitan dengan pengurusan arsip disebut manajemen kearsipan. Manajemen kearsipan adalah pekerjaan pengurusan arsip yang meliputi pencatatan, pengendalian dan pendistribusian, penyimpanan, pemeliharaan, pengawasan, pemindahan dan pemusnahan. Pekerjaan

\footnotetext{
3 Kantor Samsat Kota Bogor 2016

4 Mamik Puji Astuti, Manfaat Dokumen Keluarga Sebagai Sumber Cerita, Semarang: Heavy Rain, 2013, Hlm.43
}

tersebut meliputi siklus hidup arsip (life cycle of archive).$^{5}$

\section{Manajemen kearsipan (record} management) memiliki fungsi untuk menjaga keseimbangan arsip dalam segi penciptaan, lalu lintas dokumen, pencatatan, penerusan, pendistribusian, pemakaian, penyimpanan, pemeliharaan, pemindahan dan pemusnahan arsip. Tujuan akhir manajemen kearsipan ialah untuk menyederhanakan jenis dan volume arsip serta mendayagunakan penggunaan arsip bagi peningkatan kinerja dan profesionalitas institusi atau lembaga dengan biaya yang efektif dan efisien.

SAMSAT Kota Bogor sebagai salah satu aspek pelayanan kepada masyarakat Kota Bogor, di dalam pelaksanaannya harus lebih berpihak dan responsif terhadap kepentingan masyarakat itu sendiri. Dengan demikian setiap penjabat publik (khususnya aparat yang menangani SAMSAT) dituntut untuk lebih profesional dan meningkatkan kinerja dalam melaksanakan tugas-tugas yang diembannya. Masyarakat sudah lebih transparan dan semakin kritis serta berani untuk melakukan koreksi terhadap kekurangan dan kelalaian yang dilakukan oleh publik dalam memberikan pelayanan.

Meskipun manajemen kearsipan cenderung diterapkan dalam pengurusan arsip secara manual, namun aplikasi manajemen kearsipan yang baik dan tepat terhadap arsip manual menjadi langkah awal dan tahapan utama yang harus dijalani dalam mewujudkan sistem kearsipan yang ideal bagi organisasi. Jika manajemen kearsipan secara manual sudah berjalan baik dan tepat, maka jika di masa mendatang institusi atau lembaga memiliki rencana untuk melakukan integrasi antara manajemen kearsipan dengan teknologi informasi, kesulitan-kesulitan dan kendala yang muncul selama masa transisi penerapan teknologi informasi dalam

\footnotetext{
5 Anwar Prabu Mangkunegara, Manajemen Sumber Daya Manusia Organisasi, Bandung: Remaja Rosdakarya, 2008, Hlm.110
} 
manajemen kearsipan akan dapat diminimalisir. $^{6}$

Permasalahan pada Sistem Manajemen Pengarsipan di Samsat Kota Bogor belum terkomputerisasi dan tidak terintegrasi, dan sulitnya pencarian status kendaraan. Pemakaian komputer pada umumnya hanya untuk input dan mencetak data saja. Kurangnya pengolahan data untuk perencanaan atau pelaporan sehingga tidak adanya suatu database terpusat untuk perencanaan, pelaporan, dan pemantauan data dan Lambatnya pengusutan kasus kriminal yang terkait kendaraan bermotor. Untuk membantu memberikan alternatif pada permasalahan di atas maka diperlukan suatu sistem yang akan membantu SAMSAT Kota Bogor yang termasuk dalam kategori sistem informasi manajemen.

Penyebab terjadinya permasalahan sejak diberlakukannya kebijakan Peraturan Kapolri Nomor 5 Tahun 2012 tentang Registrasi dan Identifikasi Kendaraan Bermotor dilaksanakan timbul permasalahan-permasalahan baru, antara lain :

1. Pelayanan dalam bentuk on line tidak tersedia saat masyarakat ingin membayar pajak

2. Adanya kasus double nomor polisi kendaraan masyarakat

3. Nilai Jual Kendaraan Bermotor (NJKB) tidak tertera

4. Adanya kejadian merk kendaraan bermotor hilang

Permasalahan baru tersebut membuat data tidak dapat diproses dalam waktu dekat, tetapi waktu yang dibutuhkan untuk memperbaiki data tersebut membutuhkan waktu yang sangat lama. Sehingga masyarakat yang mendaftarkan pajaknya saat dilakukan pendaftaran pajak belum terlambat dan dikenakan sanksi, tapi saat pajak sudah ditetapkan dan akan dibayar denda sanksi tersebut timbul, dan

6 Ashar Sunyoto Munandar, Psikologi Industri dan Organisasi, Jakarta: UI-Press, 2007, Hlm. 102 denda tersebut ditanggung oleh pemilik kendaraan bermotor tersebut.

Kebijakan Kapolri Nomor 5 Tahun 2012 tentang Registrasi dan Identifikasi Kendaraan Bermotor (Regident Ranmor) berupa aplikasi Buku Pemilik Kendaraan Bermotor (BPKB) sebuah sistem yang dibuat oleh pihak kepolisian guna mempermudah masyarakat dalam melakukan pengurusan Buku Pemilik Kendaraan Bermotor (BPKB). Karena BPKB adalah dokumen pemberi legitimasi kepemilikan kendaraan bermotor yang diterbitkan Polri dan berisi identitas kendaraan bermotor dan pemilik, yang berlaku selama kendaraan bermotor tidak dipindahtangankan.

Kebijakan Kapolri Nomor 5 Tahun 2012 ini dilaksanakan dan system tersebut berjalan, dampak yang timbul di dalam masyarakat sangat jauh berbeda dari keinginan yang diharapkan oleh kebijakan tersebut. masyarakat yang selama ini merasa diberikan kemudahan dalam melakukan pengurusan surat kendaraan bermotor, sekarang menjadi kecewa, karena Kebijakan Kapolri No. 5 tahun 2012 tentang Registrasi dan Identifikasi Kendaraan Bermotor membuat sistem yang ada di Samsat Kota Bogor terbatas. Kurangnya sosialisasi terhadap Masyarakat dan Pegawai Samsat Kota Bogor berdampak negatif dengan berkurangnya masyarakat membayar pajak kendaraan bermotor.

Berdasarkan latar belakang tersebut di atas, maka dapat diidentifikasi permasalahan sebagai berikut:

1. Bagaimana mekanisme pengarsipan di Samsat Kota Bogor berkaitan dengan Peraturan Kapolri Nomor 5 Tahun 2012 tentang Registrasi dan Identifikasi Kendaraan Bermotor?

2. Bagaimana kendala dalam pengarsipan pada Samsat Kota Bogor dihubungkan dengan Peraturan Kapolri Nomor 5 Tahun 2012 tentang Registrasi dan Identifikasi Kendaraan Bermotor?

Tujuan dari penelitian ini adalah sebagai berikut : 
1. Untuk mengetahui dan menganalisis mekanisme pengarsipan di Samsat Kota Bogor berkaitan dengan Peraturan Kapolri Nomor 5 Tahun 2012 tentang Registrasi dan Identifikasi Kendaraan Bermotor.

2. Untuk mengetahui dan menganalisis kendala dalam pengarsipan pada Samsat Kota Bogor dihubungkan dengan Peraturan Kapolri Nomor 5 Tahun 2012 tentang Registrasi dan Identifikasi Kendaraan Bermotor.

Metode penelitian diperlukan guna mengumpulkan sejumlah bahan yang digunakan untuk menjawab analisis yuridis. Bertitik tolak dari permasalahan, maka metode penelitian yang digunakan adalah metode penelitian yuridis normatif yaitu hukum dikonsepsikan sebagai norma, kaidah, asas atau dogma-dogma ${ }^{7}$

\section{B. Pelaksanaan Pengarsipan di Samsat Kota Bogor}

Dalam Sistem merupakan suatu kesatuan yang terorganisir yang mengatur hubungan dalam suatu kerangka tertentu untuk mencapai tujuan tertentu, atau menurut Boedi sistem adalah sekelompok kegiatan yang saling berkaitan yang secara bersama-sama berusaha mencapai tujuan. ${ }^{8}$

Secara sepintas pekerjaan dalam sebuah organisasi kantor hanya menyangkut rangkaian kegiatan seperti merencanakan aktivitas kantor, mengorganisir pekerjaaan, mengarahkan, mengawasi dan mengadili pekerjaan kantor. Menurut L. ACKOF, Sistem adalah setiap kesatuan secara konseptual atau fisik yang terdiri dari bagian-bagian dalam keadaan saling tergantung satu sama lainnya. Atau dalam bahasa sederhana, sistem dapat diartikan sebagai sekumpulan

7 Martin Roestamy, Endeh Suhartini, dan Aal Lukmanul Hakim, Pedoman Penulisan Skripsi pada Fakultas Hukum, Program Studi Ilmu Hukum Fakultas Hukum Universitas Djuanda, Bogor, 2008, Hlm. 42

8 Martono Boedi, Arsip Korespondensi Penciptaan dan Penyimpanan, Jakarta, Pustaka Sinar Harapan, 2007, Hlm.12. unsur/elemen yang saling berkaitan dan saling mempengaruhi dalam melakukan kegiatan bersama untuk mencapai suatu tujuan.

Sistem kearsipan di Indonesia memiliki akar sejarah yang cukup panjang, paling tidak bisa dilacak dari masa administrasi Hindia Belanda. Sistemsistem yang pernah dikembangkan diharapkan menjadi bahan kajian untuk menciptakan sistem kearsipan yang komprehensif, yaitu suatu sistem kearsipan yang mampu mendukung seluruh aspek manajemen kearsipan, mulai dari penciptaan, penggunaan dan pemeliharaan sampai, dengan penyusutan. ${ }^{9}$

Sistem Kearsipan adalah rangkaian subsistem dalam manajemen kearsipan yang bekerja sama untuk mencapai tujuan agar arsip tertata dalam unit-unit informasi siap pakai untuk kepentingan operasional dengan azas bahwa hanya informasi yang tepat digunakan oleh orang yang tepat untuk kepentingan tepat pada waktu yang tepat dengan biaya serendah mungkin. Subsistem dalam sistem kearsipan mencakup tata naskah dinas (form management), pengurusan surat (correspondence management), penataan berkas (files management), tata kearsipan dinamis (records management), dan tata kearsipan statis (archives management). ${ }^{10}$

Pengelolaan arsip sebenarnya telah dimulai sejak suatu surat (naskah, warkat) dibuat atau diterima oleh suatu kantor atau organisasi sampai kemudian ditetapkan untuk disimpan, selanjutnya disusutkan (retensi) dan atau dimusnahkan. Oleh karena itu, di dalam kearsipan terkandung unsur-unsur kegiatan penerimaan, penyimpanan, temu balik, dan penyusutan arsip. Arsip disimpan karena mempunyai nilai atau kegunaan tertentu (lihat uraian di atas). Oleh karena itu, hal yang perlu diperhatikan dalam hal ini ialah bagaimana prosedurnya, bagaimana cara penyimpanan yang baik, cepat, dan tepat, sehingga

\footnotetext{
9 Wursanto, Kearsipan 1, Yogyakarta, Kanisius, 2011, Hlm.55.

10 Ibid., Hlm. 11
} 
mudah atau ditemukan kembali sewaktuwaktu diperlukan, serta langkah- langkah apa yang perlu diikuti/dipedomani dalam penyimpanan arsip tersebut.

Secara etimologis istilah arsip dalam bahasa Belanda yaitu "archief", dan dalam bahasa Ingris disebut "arcihive", berasal dari kata "arche" bahasa Yunani yang berarti permulaan. Kemudian dari kata "arche" berkembang menjadi kata " $t a$ archia" yang berarti catatan. Selanjutnya kata "ta archia" berubah lagi menjadi kata "archeon" yang berarti "gedung pemerintahan". ${ }^{11}$

Registrasi berasal dari bahasa Inggris 'registration' yang memiliki arti daftar. Registrasi merupakan proses melakukan pengisian sejumlah hal atau memenuhi persyaratan dari suatu objek yang nantinya dibutuhkan untuk mengikuti suatu kegiatan. $^{12}$

Registrasi adalah suatu kegiatan pencatatan yang dilakukan pertama kali pada saat melakukan pendaftaran. Pengertian pendaftaran disini pada dasarnya hanya untuk memperlancar dan mempermudah dalam proses pendaftaran kendaraan bermotor. ${ }^{13}$

Kebijakan Kapolri Nomor 5 Tahun 2012 tentang Regident Ranmor berupa aplikasi Buku Pemilik Kendaraan Bermotor (BPKB) sebuah sistem yang dibuat oleh pihak kepolisian guna mempermudah masyarakat dalam melakukan pengurusan Buku Pemilik Kendaraan Bermotor (BPKB). Karena BPKB adalah dokumen pemberi legitimasi kepemilikan kendaraan bermotor yang diterbitkan Polri dan berisi identitas kendaraan bermotor dan pemilik, yang berlaku selama kendaraan bermotor tidak dipindahtangankan.

\footnotetext{
11 Suparjati, Tata Usaha dan Kearsipan (Seri Administrasi Perkantoran), Yogyakarta, Kanisius, 2010, Hlm.78.

12 Anton Moeliono, Kamus Besar Bahasa Indonesia, Jakarta, Balai Pustaka, 2010, Hlm.231

13 Teguh Wahyono, Sistem Informasi Konsep Dasar Analisis Desain Dan Implementasi. Yogjakarta, Graha Ilmu, 2014, Hlm.119.
}

Untuk melaksanakan ketentuan Pasal 67 Ayat (4) Undang-Undang Nomor 22 Tahun 2009 tentang Lalu Lintas dan Angkutan Jalan, perlu menetapkan Peraturan Presiden tentang Penyelenggaraan Sistem Administrasi Manunggal Satu Atap Kendaraan Bermotor.

Registrasi dan Identifikasi Kendaraan Bermotor adalah fungsi Kepolisian untuk memberikan legitimasi asal usul dan kelaikan, kepemilikan serta pengoperasian Ranmor, fungsi kontrol, forensik Kepolisian dan pelayanan kepada masyarakat melalui verifikasi, pencatatan dan pendataan, penomoran, penerbitan dan pemberian bukti registrasi dan identifikasi Ranmor, pengarsipan serta pemberian informasi.

$$
\text { Pasal } 4 \text { ayat (1) Peraturan Kapolri }
$$

Nomor 5 Tahun 2012 tentang Registrasi dan Identifikasi Kendaraan Bermotor disebutkan bahwa Regident Ranmor meliputi:

1. Registrasi Ranmor baru;

2. Registrasi perubahan identitas Ranmor dan pemilik;

3. Registrasi perpanjangan Ranmor; dan/atau

4. Registrasi pengesahan Ranmor.

Selain kegiatan sebagaimana dimaksud pada ayat (1), pelayanan Regident Ranmor juga meliputi:

1. Pemblokiran dokumen Regident Ranmor yang terkait tindak pidana;

2. Penggantian dokumen Regident Ranmor; dan

3. Penghapusan nomor registrasi Ranmor.

\section{Mekanisme Pengarsipan di Samsat Kota Bogor Dihubungkan Dengan Peraturan Kapolri Nomor 5 Tahun 2012 tentang Registrasi dan Identifikasi Kendaraan Bermotor}

Pelayanan publik adalah tugas dari pemerintah dan negara dalam memberikan kebutuhan kepada masyarakatnya yang dapat menjalankan sistem suatu negara, sering dapat dikatakan dalam melaksanakan tuntutan pekerjaan 
masyarakat pada umumnya akan berurusan dengan pelayan publik baik dari segi bidang apapun pengurusan ijin, kependudukan, pekerjaan dan sebagainya, di dalam aktivitas masyarakat setiap hari berurusan di dalam bidang administrasi publik untuk mencapai tujuan yang dimana harus mentaati prosedur yang berlaku di negara tersebut atau bisa bilang aturan main, seperti di negara Indonesia banyak sekali masalah administrasi publik baik itu dari segi syarat-syaratnya untuk memperoleh misalnya suatu ijin dari pemerintah, tumpang tindih kebijakan, sampai dengan sikap atau moralitas pelayanan publik yang masih kurang dari apa yang diharapkan oleh masyarakat, oleh karena itulah sekiranya perlu untuk memperbaiki moralitas pelayanan publik yang baik supaya harapan masyarakat bisa terpenuhi.

Penyimpangan-penyimpangan

tidak sejalan dan bahkan bertentangan dengan ajaran yang terkandung di dalam Pancasila. Sebagai ideologi negara, Pancasila sebenarnya sudah mengatur prinsip-prinsip tata kehidupan masyarakat Indonesia, berupa nilai-nilai luhur budaya bangsa yang dapat dijadikan pedoman bagi seluruh rakyat Indonesia untuk mencapai kemajuan dalam hidup berbangsa dan bernegara. Karena itu mestinya senantiasa menjadi acuan digunakan sebagai pedoman tingkah laku bangsa Indonesia dalam kehidupan sehari-hari.

Berdasarkan Peraturan Presiden Republik Indonesia Nomor 5 Tahun 2015 Tentang Penyelenggaraan Sistem Administrasi Manunggal Satu Atap Kendaraan Bermotor, bahwa Registrasi dan Identifikasi Kendaraan Bermotor yang selanjutnya disebut Regident Ranmor adalah fungsi Kepolisian untuk memberikan legitimasi asal usul dan kelaikan, kepemilikan serta pengoperasian ranmor, fungsi kontrol, forensik kepolisian dan pelayanan kepada masyarakat melalui verifikasi, pencatatan dan pendataan, penomoran, penerbitan dan pemberian bukti registrasi dan identifikasi Ranmor, pengarsipan serta pemberian informasi.
Registrasi dan Identifikasi Kendaraan Bermotor (Regident Ranmor) bertujuan untuk tertib administrasi, pengendalian dan pengawasan kendaraan bermotor yang dioperasikan di Indonesia, mempermudah penyidikan pelanggaran dan atau kejahatan, perencanaan, operasional manajemen dan rekayasa lalu lintas dan angkutan Jala dan perencanaan pembangunan nasional.

Registrasi dan Identifikasi

Kendaraan Bermotor (Regident Ranmor) meliputi registrasi ranmor baru, registrasi perubahan identitas ranmor dan pemilik, registrasi perpanjangan ranmor dan atau registrasi pengesahan ranmor. Selain kegiatan tersebut regident ranmor juga meliputi pemblokiran dokumen regident ranmor yang terkait tindak pidana, penggantian dokumen regident ranmor dan penghapusan nomor registrasi ranmor. Pada setiap kegiatan diperlukan bantuan data dan informasi. Demikian pula pada kegiatan pengambilan keputusan yang kita kenal dengan manajemen. Bantuan data dan informasi yang benar dapat dihasilkan secara efektif dan efisien.

Tugas kepolisian tak hanya itu saja melainkan mencakup penjagaan, pengaturan, pengawalan, dan patroli, pendidikan masyarakat dan rekayasa lalu lintas, penyidikan kecelakaan lalu lintas dan penegakan hukum dalam bidang lalu lintas, guna memelihara keamanan, ketertiban dan kelancaran lalu lintas. Para petugas kepolisian pada tingkat pelaksana menindaklanjuti kebijakan-kebijakan pimpinan terutama yang berkaitan dengan pelayanan di bidang SIM, STNK, BPKB dan penyidikan kecelakaan lalu lintas.

Arsip merupakan suatu sekumpulan dokumen yang di kumpulkan menurut suatu masalah atau logika dan disimpan untuk maksud tertentu. Tolak ukur keberhasilan suatu organisasi tidak hanya dilihat dari kemampuannya untuk memperoleh keuntungan, namun harus diimbangi kegiatan pengelolaan kearsipan yang sistematis, efisien, dan praktis yang saling mendukung antara satu dengan lainnya. Sehingga dapat meningkatkan 
citra organisasi sebagai lembaga yang terpecaya.

Prosedur pelaksanaan penyimpanan arsip pada Kantor Bersama Samsat Kota Bogor menggunakan prosedur penyimpanan Manual dan Elektronik (komputerisasi). Dengan adanya ruang penyimpanan arsip sangat perlu sekali karena mengingat begitu pentingnya mengenai keberadaan arsip. Dalam penyimpanan arsip membutuhkan metode prosedur kearsipan yang baik dan tidak boleh di anggap remeh. Adapun yang menjadi metode prosedur kearsipan pada kantor bersama Samsat Kota Bogor adalah sebagai berikut:

1. Penerimaan arsip Tahap awal dalam proses pengarsipan adalah penerimaan arsip yang berisi data-data mengenai wajib pajak dan pajak kendaraan bermotornya. Adapun proses pelaksanaannya adalah sebagai berikut:

a. Wajib pajak pertama sekali datang ke kantor samsat dengan membawa beberapa persyaratan untuk mengurus pajak kendaraan yaitu membawa BPKB asli. STNK asli, KTP asli. Kemudian membeli formulir pendaftaran. Setelah formulir diterima, wajib pajak mengisi formulir tersebut lalu menyerahkan formulirnya kebagian arsip.

b. Petugas bagian arsip kemudian melakukan pengecekan terhadap data-data yang ada dalam formulir tersebut. Setelah selesai petugas arsip memberikan blanko kartu kendaraan bermotor kepada wajib pajak. Adapun isi dari blanko tersebut adalah data wajib pajak, jenis kendaraan wajib pajak, besarnya pajak dan tanggal pembayaran pajak. Data-data yang ada pada blanko inilah yang nantinya akan disimpan oleh pihak Kantor Bersama Samsat Kota Bogor sebagai arsip wajib pajak apabila di tahun berikutnya wajib pajak akan melakukan pembayaran pajak.

c. Setelah blanko selesai diisi, petugas arsip akan meneruskan blanko tersebut kebagian Penelitian Dokumen untuk dicek dan apabila memenuhi syarat maka petugas penelitian dokumen akan memberikan paraf pada blanko tersebut. Setelah selesai dari bagian penelitian dokumen, blanko tersebut kemudian diteruskan ke bagian Entry Data.

d. Petugas Entry data memasukkan data nomor Plat wajib pajak ke dalam komputer untuk mengecek besarnya pajak yang harus dibayar oleh wajib pajak. Setelah diketahui besarnya pajak yang harus dibayar, maka wajib pajak melakukan registrasi pembayaran. e. Setelah pajak dibayar blanko tersebut akan diteruskan kembali ke bagian arsip untuk dilakukan pencatatan pembayaran pajak serta masa berlaku pajak kendaraan selama 1 tahun. Blanko inilah yang akan disimpan pihak Samsat sebagai arsip.

2. Pelabelan dan Penentuan Sarana Simpan Tahap kedua dalam proses metode pengarsipan adalah pelabelan dan penentuan sarana simpan. Label ditempelkan pada media simpan dan dipergunakan sebagai identitas berkas. Dalam pencantuman label, meliputi: Tahun dan Bulan Arsip Disimpan berupa data Bulan, dan Tahun pembayaran pajak Sarana simpan yang dipergunakan untuk menyimpan arsip adalah: Lemari Tahan api. 
a. Dipergunakan untuk menyimpan blanko (kartu kendaraan bermotor)

b. Lemari tahan api ditempatkan di ruang arsip

c. Arip disusun berdasarkan bulan, dan tahun pembayaran pajak kendaraan.

3. Pemeliharaan Arsip Pemeliharaan Arsip di Kantor Samsat Kota Bogor dilakukan dengan cara:

a. Menjaga suhu ruangan dengan temperatur ruangan antara 25 $27 \mathrm{C}$.

b. Kelembaban ruangan antara 5060 RH (Relative Humidity)

c. Dilarang merokok di Area penyimpanan arsip

d. Memelihara dan menjaga kebersihan ruangan arsip

e. Mengatur sistem pencahayaan agar tidak merusak arsip

4. Penyusutan Arsip

Penyusutan Arsip adalah kegiatan pengurangan arsip atau dasar nilai guna dan retensi arsip dengan melalui pemindahan, pemusnahan maupun penyerahan arsip. Adapun cara yang dilakukan Kantor Bersama Samsat Kota Bogor dalam melakukan penyusutan arsip adalah memindahkan arsip yang umurnya lebih dari 5 tahun ke dalam gudang peyimpanan. Hal ini dilakukan untuk mengurangi ruang penyimpanan. Akan tetapi walaupun arsip tersebut telah dipindahkan ke gudang, datanya masih tersimpan pada data base Kantor Bersama Samsat Kota Bogor.

Kebijakan Kapolri Nomor 5 tahun 2012 ini dilaksanakan dan sistem manajemen pengarsipan tersebut berjalan, dampak yang timbul di dalam masyarakat sangat jauh berbeda dari keinginan yang diharapkan oleh kebijakan tersebut. masyarakat yang selama ini merasa diberikan kemudahan dalam melakukan pengurusan surat kendaraan bermotor di Kantor Samsat, sekarang menjadi kecewa, karena Kebijakan Kapolri Nomor 5 Tahun 2012 tentang Registrasi dan Identifikasi Kendaraan Bermotor/BPKB on-line membuat sistem yang ada di KUPTD Kijang terbatas. Landasan Hukum Implementasi Kebijakan Kapolri Nomor 5 Tahun 2012 tentang Registrasi dan Identifikasi Kendaraan Bermotor/on-line adalah turunan dari Undang-undang Nomor 28 Tahun 2009 tentang Lalu Lintas dan Angkutan Jalan. Kurangnya sosialisasi terhadap Masyarakat dan Pegawai Kantor Samsat Kota Bogor berdampak negatif dengan berkurangnya masyarakat membayar pajak kendaraan bermotor. Kebijakan Peraturan Kapolri Nomor 5 Tahun 2012 ini tidak hanya berpengaruh kepada masyarakat Kota Bogor (wajib pajak) saja tetapi, berpengaruh besar terhadap Kantor Samsat Kota Bogor, karena target yang telah ditetapkan oleh Dinas Pendapatan Daerah Kota Bogor untuk Kantor Samsat Kota Bogor jelas menurun.

\section{Hambatan Dalam Sistem Manajemen Pengarsipan di Samsat Kota Bogor}

Hambatan dalam pelaksanaan sistem manajemen pengarsipan di Kantor Samsat Kota Bogor dalam hal registrasi dan identifikasi kendaraan bermotor adalah:

1. Kurangnya pengertian terhadap pentingnya arsip. Belum atau kurang dipahaminya pengertian arsip mengakibatkan fungsi arsip sebagai pusat ingatan organisasi tidak tercapai, dan akhirnya tugas-tugas di bidang kearsipan dipandang rendah.

2. Bertambahnya volume arsip secara terus menerus mengakibatkan tempat dan peralatan yang tersedia tidak dapat menampung arsip lagi.

3. Belum dimilikinya pedoman tata kerja kearsipan yang diberlakukan secara baku di suatu kantor/organisasi, sehingga masing-masing petugas melaksanakan pekerjaannya tanpa keseragaman dan tujuan yang jelas.

4. Penggunaan arsip oleh pengelola atau oleh pihak lainnya yang membutuhkan 
jangka waktu yang lama, dan bahkan

Hal ini akan menghambat pihak lain yang juga membutuhkan arsip tersebut.

5. Tidak dapat atau sulit ditemukannya kembali arsip dengan cepat dan tepat bila diperlukan oleh pihak lain. Hal tersebut mungkin karena belum sempurnanya sistem atau karena petugas yang belum/kurang terampil.

Untuk mengatasi masalah-masalah yang ada dalam pengarsipan di agar tidak merugikan lembaga, adapun langkahlangkah yang bisa ditempuh antara lain:

1. Harus menggunakan sistem penyimpanan yang tepat

2. Perlu adanya pengaturan prosedur peminjaman di samping pengawasan/kontrol dan pengendalian yang tepat

3. Memperluas tempat penyimpanan dan mengefektifkan ruangan serta peralatan yang ada.

4. Fasilitas kearsipan harus memenuhi syarat dan mengikuti perkembangan zaman

5. Secara rutin diadakan perawatan dan pencegahan kerusakan

6. Petugas arsip harus memenuhi syarat

7. Mengikutsertakan para pengelola arsip dalam kursus-kursus atau diklat-diklat kearsipan dan penggunaan teknologi yang canggih

8. Melakukan penyusutan dan pemusnahan secara rutin terhadap arsip-arsip yang sudah tidak terpakai.

\section{E. Kesimpulan}

Kesimpulan yang dapat diambil dari penelitian ini adalah:

1. Mekanisme pengarsipan di Samsat Kota Bogor berkaitan dengan Peraturan Kapolri Nomor 5 Tahun 2012 tentang Registrasi dan Identifikasi Kendaraan Bermotor meliputi: a) Penerimaan arsip, b) Pelabelan arsip, c) Pemelihara arsip, dan d) Penyusutan arsip.

2. Kendala dalam pengarsipan pada Samsat Kota Bogor dihubungkan dengan Peraturan Kapolri Nomor 5 kadang-kadang tidak dikembalikan. Tahun 2012 tentang Registrasi dan Identifikasi Kendaraan Bermotor diantaranya: a) Kurangnya pengertian terhadap pentingnya arsip, b) Bertambahnya volume arsip, c) Belum dimilikinya pedoman tata kerja kearsipan yang diberlakukan secara baku, d) Penggunaan arsip oleh pengelola atau oleh pihak lainnya yang membutuhkan jangka waktu yang lama, e) Tidak dapat atau sulit ditemukannya kembali arsip dengan cepat dan tepat. 


\section{DAFTAR PUSTAKA}

Abdul Azis Hakim, Negara Hukum dan Demokrasi Di Indonesia, Yogyakarta,Pustaka Pelajar, 2011.

Agus Dwiyanto, Mewujudkan Good Governance Melalui Pelayanan Publik, Yogyakarta, Gadjah Mada University Press, 2008.

Anton Moeliono, Kamus Besar Bahasa Indonesia, Jakarta, Balai Pustaka, 2010.

Arief M. Isa, Pembuktian dan Daluarsa, Jakarta, PT. Intermasa, 1986.

Arisandy ST, Wahyu, Lalu Lintas Refleksi Intelektualitas, Riau, 2013.

Astuti Mamik Puji, Manfaat Dokumen Keluarga Sebagai Sumber Cerita, Heavy Rain, Semarang, 2013.

Badri Munir Sukoco, Manajemen Administrasi Perkantoran Modern, Surabaya, Erlangga, 2007.

Bambang Yudoyono, Otonomi Daerah, Jakarta, Pustaka Sinar Harapan, 2013.

Barthos Basir. Manajemen Kearsipan. Jakarta, PT Bumi Aksara, 2013.

Cambell Black, Henry, Black's Law Dictionary With Tonounciations, Fifth Edition, West Publishing \& Co. USA, 1979.

Daliyo, JB., Pengantar Ilmu Hukum, Jakarta, PT. Prenhallindo, 2001. Dimyanti, Khudzaifah dan Kelik Wardiono. Metode Penelitian Hukum (Buku Pegangan Kuliah). UMS, Surakarta, 2004.

Gamer, Bryan A., Black's Law Dictionary, West Group, ST.PAUL, MINN, Seventh Edition, 1999.

Hadi Abu Bakar, Pola Kearsipan Modern, Jakarta, Djambatan, 2010.

Kadir, Pengenalan Sistem Informasi, Yogyakarta, Andi Press, 2013.

Kaelan, Pendidikan Pancasila, Yogyakarta, Paradigma, 2008.

Kusumaatmaja, Mochtar, Konsep-konsep Hukum dalam Pembangunan, Bandung, Alumni, 2006.

Lijan Sinambela Poltak, Reformasi Pelayanan Publik, Jakarta, Bumi Aksara, 2006.

Luthfi Kurniawan, Pelayanan Publik Bukan Untuk publik, Jakarta, Yappika, 2006.

M. Khoirul Anwar dan Assianti, Oetojo S. Aplikasi Sistem Informasi Manajemen Bagi Pemerintah Daerah Di Era Otonomi Daerah, Yogyakarta, Pustaka Pelajar, 2004.

Mangkunegara, Anwar Prabu, Manajemen Sumber Daya Manusia Organisasi, Bandung: Remaja Rosdakarya, 2008.

Martiman P, Disiplin Dalam Lalu Lintas, Jakarta, Bumi Aksara, 2007.

Martin Roestamy, Endeh Suhartini, dan Aal Lukmanul Hakim, Pedoman Penulisan Skripsi pada Fakultas Hukum, Program Studi Ilmu Hukum Fakultas Hukum Universitas Djuanda, Bogor, 2008.

Martono Boedi, Arsip Korespondensi Penciptaan dan Penyimpanan, Jakarta, Pustaka Sinar Harapan, 2007.

Marzuki, Peter Mahmud, Penelitian Hukum, Jakarta, Elips, 2006.

Moeliono, Anton M., Kamus Besar Bahasa Indonesia, Jakarta, Gramedia, 2003.

Moenir, Manajemen Pelayanan Umum Indonesia, Jakarta: Bumi Aksara, 2007.

Mulyono Sularso, Mushim Dan Marinim, Dasar-Dasar Kearsipan, Yogyakarta, Erlangga, 2010.

Munandar, Ashar Sunyoto, Psikologi Industri dan Organisasi, Jakarta: UI-Press, 2007.

Naning, Ramdlon, Ketertiban Lalu Lintas, Jakarta, Gramedia, 2010.

Nico Andrianto, Transparasi dan Akuntabilitas Publik Melalui e-Government, Malang, Bayumedia Publishing, 2007.

Richardus Eko Indrajit, E-Government Strategi Pembangunan Dan Pengembangan Sistem Pelayanan Publik Berbasis Teknologi Digital, Yogyakarta, Andi Offset, 2006. 
Rangkuti, Jasa Pelayanan. Bandung: Remajarosdakarya, 2008.

Sedarmayanti, Tata Kearsipan dengan Memanfaatkan Teknologi Modern, Jakarta, Ilham Jaya Offset, 2010.

Suparjati, Tata Usaha dan Kearsipan (Seri Administrasi Perkantoran), Yogyakarta, Kanisius, 2010.

Sutarto, Sekretaris Dan Tata Warkat, Yogyakarta: Gajah Mada University Press, 2009.

Sutarto, Dasar-dasar Kepemimpinan Administrasi, Yogyakarta: Gadjah Mada University Press, 2007.

Teguh Wahyono, Sistem Informasi Konsep Dasar Analisis Desain Dan Implementasi. Yogjakarta, Graha Ilmu, 2014.

The Liang Gie, Administrasi Perkantoran, Yokyakarta, Modern Liberty, 2009.

Utrecth, E., dalam Ni'matul Huda, Hukum Tata Negara Indonesia, Jakarta, PT. Raja Grafindo Persada, 2010.

Waluyo, Bambang, Sistem Pembuktian dalam Peradilan Indonesia, Jakarta, Sinar Grafika, $\underline{1996 .}$.

Wursanto, Kearsipan 1, Yogyakarta, Kanisius, 2011.

Wursanto, Kearsipan 2, Yogyakarta, Kanisius, 2011.

Zulkifli Amsyah, Manajemen Kearsipan, Jakarta, PT Gramedia Pustaka Utama, 2014.

\section{Perundang-undangan}

Undang-Undang Dasar Negara Republik Indonesia Tahun 1945.

Undang-undang Nomor 7 Tahun 1971 tentang Ketentuan Pokok Kearsipan.

Undang-Undang Nomor 22 Tahun 2009 tentang Lalu Lintas dan Angkutan Jalan.

Undang-undang Nomor 28 Tahun 2009 tentang Lalu Lintas dan Angkutan Jalan.

Undang-undang Nomor 43 Tahun 2009 tentang Kearsipan.

Undang-Undang Nomor 2 Tahun 2009 tentang Kepolisian Negara Republik Indonesia.

Ketetapan MPR Rl No. Vll/MPR/ 2000 tentang Peran TNl dan Polri.

Peraturan Pemerintah Nomor 44 Tahun 1993 tentang Kendaraan dan Pengemudi.

Peraturan Pemerintah Nomor 50 Tahun 2010 tanggal 25 Mei 2010 tentang Jenis dan Tarif Atas Jenis Penerimaan Negara Bukan Pajak (PNBP).

Peraturan Pemerintah Nomor 80 Tahun 2012 tentang Tata Cara Pemeriksaan Kendaraan Bermotor Di Jalan Dan Penindakan Pelanggaran Lalu Lintas Dan Angkutan Jalan.

Peraturan Presiden Republik Indonesia Nomor 5 Tahun 2015 Tentang Penyelenggaraan Sistem Administrasi Manunggal Satu Atap Kendaraan Bermotor.

Keputusan Menteri Pendayagunaan Aparatur Negara Nomor 81 Tahun 1993 tentang Pedoman Tata Laksana Pelayanan.

Keputusan Presiden Nomor 89 Tahun 2000 tentang Kedudukan Kepolisian Negara Republik Indonesia.

Keputusan Menteri Pendayagunaan Aparatur Negara Nomor 63 Tahun 2003 tentang Standar Pelayanan Publik.

Peraturan Kapolri Nomor 5 Tahun 2012 tentang Registrasi dan Identifikasi Kendaraan Bermotor.

Surat Telegram Kapolri No: STR /72/II/2013 Tanggal 14 Pebruari 2013.

Surat Keputusan Kapolri No. Pol.: SKEP/443/IV/1998 tentang Buku Petunjuk Teknis tentang Penggunaan Blanko Tilang.

\section{Literatur}

Kantor Samsat Kota Bogor, Tugas Pokok dan Fungsi Samsat, Bogor, 2016. 


\section{Sumber Internet}

http: // komisikepolisianindonesia.com / hukum / read / 208 /naskah - akademik - ruu - llaj ii. Html.

http://www.jateng.polri.go.id/home.php?menu=6.

http : // www. organisasi. Org / 1970 / 01 / alasan - kenapa - kita - harus - membawa - sim dan - stnk-saat-mengendarai-kendaraan-mobil-motor.html.

http://www.pikiran-rakyat.com/node/229379, Pikiran Rakyat Online, Bandung, 2014. 